\title{
In Memory of Carlos Alfredo Yorio
}

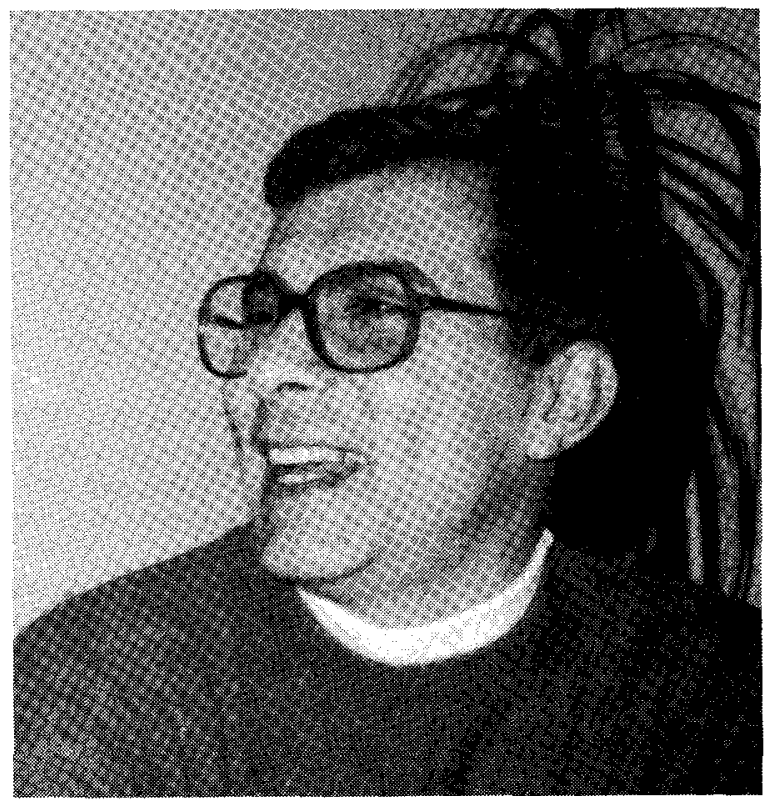

\section{Carlos Alfredo Yorio}

June 19, 1940-January 23, 1989

This section is dedicated to the memory of Carlos Alfredo Yorio. Carlos made a profound contribution to the field of second language teaching in Canada. He was President of TESL Ontario in 1976-77, Ontario Representative to the founding meeting of TESL Canada in 1977 and Second VicePresident of TESOL from 1978 to 1980. In addition to his activities within these professional associations, Carlos served the Canadian TESL community through numerous conference presentations and plenary addresses for associations such as SPEAQ, TESL Ontario and TEAL. In his career at the University of Toronto, he was Coordinator of ESL Programmes, School of Continuing Studies from 1973 to 1977, Academic Coordinator of the TESL Certificate Programme, Woodsworth College from 1973 to 1983 and a professor in the Department of Linguistics from 1973 to 1984.

Carlos' publications are testimony to his significant and wide-ranging contribution to second language teaching and learning. In addition, some of his many friends, colleagues and students pay tribute to Carlos' enormous influence on their professional and personal lives. 


\section{Publications}

1971 "Some Sources of Reading Problems in Foreign Language Learners", LANGUAGE LEARNING, Vol. 22, No. 2, pp. 107-115.

1972 Review of Readings on English as a Second Language, edited by K. Croft, LANGUAGE LEARNING, Vol. 22, No. 2, pp. 305-307.

1973 "The Generative Process of Intonation", LINGUISTICS, No. 97, pp. 111-125.

1974 Review of Teaching English as a Second Language, by Robert and Frieda Politzer, LANGUAGE LEARNING, Vol. 24, No. 1, pp. 151-153.

1975 "E.S.L. at the College Level", TESL TALK, Vol. VI, No. 3, pp. 62-67.

1976 "Discussion of Explaining Sequence and Variation in Second Language Acquisition", LANGUAGE LEARNING, Special Issue No. 4, Papers in Second Language Acquisition (Proceedings of the 6th Annual Conference on Applied Linguistics, University of Michigan), pp. 59-63.

1976 TESL-A Selected Annotated Bibliography for Teacher Training in Canada-1976. Published by the Ministry of Culture and Recreation, Citizenship Branch, Province of Ontario.

1976 Ingles Para Defenderse, in collaboration with Lillian Butovsky and John McHugh. Published by the Ministry of Culture and Recreation, Citizenship Branch, Province of Ontario (pp. 1-77)

Note: Translated into Italian Prima frasi d'inglese (1979)

1977 ON TESOL 77-Teaching and Learning English as a Second Language: Trends in Research and Practice, edited with $\mathrm{H}$. Douglas Brown and Ruth Crymes. TESOL, Georgetown University.

1978 The Teaching of English as a Second Language in Ontario: Current Issues and Problems, with J. Handscombe, B. Tonkin, M. Tyacke, and A. Wilson. Published by the TESL Association of Ontario.

1979 "Adult Views on Foreign Language Teaching Methods", with Joanne Harack Hayne, OPTIONS, Educational Development \#4, University of Toronto.

Note: Translated into French to appear in Options nouvelles en didactique $d u$ francais langue etrangere, fonctionelles, sociolinguistiques, semiolinguistiques. Ed. by P.R. Leon and Jack Yashinsky; Marcel Didier, Canada, 1981. 
1980 "The Teacher's Attitude Toward the Student's Output in the Second Language Classroom", in Catesol Occasional Papers, \#6, Fall 1980 (pp. 1-8), California Association of Teachers of English to Speakers of Other Languages.

Note: Reprinted in TEAL Occasional Papers, Vol. 5, 1981 under the title "The Teachers' Attitudes to Student Errors". (pp. 53-61), British Columbia Association of Teachers of English as an Additional Language.

Also reprinted in Pre-Service Training Project for Vocational Teachers of the Limited English Speaking, Illinois Office of Education, Department of Adult, Vocational and Technical Education.

1980 "Conventionalized Language Forms and The Development of Communicative Competence", TESOL Quarterly, Vol. XIV, \#4, pp. 433-442.

Note: This paper was selected for inclusion as recommended reading in the Biomedical Information Service Bulletin of the University of Sheffield, England, Vol. 36, \#2.

1980 Review of Bilingual, ESOL and Foreign Language Teacher Preparation: Models, Practices, Issues, ed. by J. Fanselow and R. Light (TESOL, 1977), Canadian Modern Language Review, Vol. 36, \#4, pp. 765-766.

1980 ON TESOL 79 The Learner in Focus, Edited with K. Perkins and J. Schachter. TESOL, Georgetown University.

1981 WHO DID IT? A Crime Reader for Students of English, with L.A. Morse. Prentice-Hall, New Jersey.

1981 "Teaching Methods, The Brain, and other Simple Matters, or Are We Ready for Applied Neurolinguistics?" TESL TALK, Vol. 12, \#'s 1 and 2, Ontario Ministry of Culture and Recreation, pp. 50-58.

Note: Reprinted in Toronto Working Papers in Linguistics, Vol. 2, 1981, pp. 226-244.

1982 Review of IDIOMatically Speaking, edited by J. McConochie, E. Block, G. Brookes, and B. Gonzales, NYS ESOL BEA, 1981, Idiom, 1982.

1984 "The State of the Art in Second Language Teaching and Learning: A Linguistic Perspective" in Proceedings of the 15th Annual Symposium of the Canadian Association of Applied Linguistics, Autumn 1984, Vol. 6, \#2, pp. 115-122. 
1985 Review of David Lightfoot's The Language Lottery: Toward a Biology of Grammars (MIT Press, 1982) in The McGill Journal of Education, Winter 1985, Vol. 20, \#1, pp. 92-93.

1985 "The ESL Reading Class: Reality or Unreality" in The Contexts of Reading, Hedley, C. and Baratta, T. (Eds.), Ablex Publishing, Norwood, N.J. (Chapter 10, pp. 151-164).

1985 "Prosodic Domains in Foreigner Talk Discourse" (with P. Avery and S. Ehrlich) in Input in Second Language Acquisition, S. Gass and C. Madden (Eds.), Newbury House Publishers (Chapter 13, pp. 214-229).

1986 "Consumerism in Second Language Learning and Teaching", The Canadian Modern Language Review, Vol. 42, \#3, pp. 668-687.

1986 "Creative Collaboration in Curricula" in Proceedings of the Symposium on Language and the World of Work in the 21st Century, Department of Education, The Commonwealth of Massachusetts, pp. 73-80.

1987 Introduction to The Teaching of Pronunciation by P. Avery and S. Ehrlich, Special Volume of TESL Talk, Ontario Ministry of Citizenship and Culture, Ontario, Canada. (pp. 6-7).

1987 "An essential Bibliography for TESOL" in The TESOL Newsletter, Special Anniversary Issue, edited by J. Haskell, TESOL, Washington, D.C. (Vol. XXI, \#2).

1987 "Is it or Isn't it? The Duality of Parodic Crime Fiction" (with L. Paravisini) in Comic Crime, ed. by E.F. Bargainnier, The Popular Press, Bowling Green State University, (pp. 181-193).

1987 "Building Multiple Bridges: Eclecticism in Language Teaching", TESL Canada Journal (Vol. 5, \#1, pp. 91-100) S. Fraser University, B.C., Canada.

Reprinted by the University of Saskatchewan (Division of Extension and Community Relations) for an Independent Study Teacher-training textbook (1988).

Reprinted by Teaching and Learning English, EFL Teachers' Association, Cordoba, Argentina (Vol. 3, 1988, pp. 2-6).

1988 "Bilingual Education: Getting it all Together", Equity and Excellence/School of Education Quarterly, The University of Massachusetts, (Issue 136, Vol. 23, \#4, pp. 8-13).

1988 "Language Facilitation: A Way of Improving the Odds" (with E. Klein and P. Enright) in Proceedings of the 1987 CUNY ESL Council Conference, ed. by L. Fox, CUNY. (Forthcoming). 

Bilingualism Across the Life Span, ed. by K. Hyltenstam and L. Obler, Cambridge University Press (Forthcoming).

"Discourse Structure and the Negotiation of Comprehensible Input" (with S. Ehrlich and P. Avery), Studies in Second Language Acquisition, Vol. XI (Forthcoming).

\section{Tributes}

With Carlos, uniquely, I went through a period where it was hard for me to separate his personal being from his professional one. With most of our colleagues, splitting the persons and their professions is hardly a problem. I mean, I never confused the gangling anglophile down the hall with the Great Vowel Shift, or saw the pert stylistician in the photocopy room as an instance of Temporal Linking. But with Carlos, I went through an academic year or two when, every time I saw him coming, I thought, Aha! the Perfect Monitor.

The thought did not come to me out of nowhere. It was planted there by Carlos himself. It was a time-1979-80 or thereabouts, as I recallwhen Carlos's main research interests focussed on second-language accents. He was interested, naturally, in whether the accents of adult ESL speakers could be improved and, if so, how. He was also interested in why ESL speakers had accents in the first place.

There was a corollary to the 'why' question. Carlos wanted to know why he himself, as an adult ESL speaker, had no-well, almost noaccent. Since our discussions of these matters took place not in lecture halls or language labs but in coffee shops and corridors, I mainly heard about the corollary. He seemed to be engaged, I once told him, in research designed to let the world know why he spoke English so well. I meant it facetiously, but he thought that was a pretty good way to put it.

Put that way, it seems solipsistic. It does, however, generalize. He was not the only adult speaker whose English bore little trace of its secondariness, although they are few. Except when he was excited, the only detectable features of his accent were occasional, and very slight, tensing of [I] and occasional nasality of some vowels. If you didn't know in advance 
that he was a native speaker of Spanish, you would probably never have guessed from these clues that he was not a native speaker of English. When he got excited-as one time at a departmental meeting, when some issue that I have now forgotten caused him to jump up and down on the spot while expostulating at top speed for about five minutes-more of the vowels tensed and nasalised, and his intonation tended to stay level at phrasal junctures. But most of the time he was unaccented, and that was a source of pride for him.

Around this same time, he travelled to several far-flung places to present a lecture about ESL accents in which the punch-line was his admission at the end that his own (lack of) accent cast doubt upon many of the theories he had just been discussing.

Carlos particularly liked to bring two concepts to bear on the question of ESL accents. One was monitoring. He was convinced that one of the crucial ways in which ESL speakers varied was in the degree of on-line correcting they exercised while speaking. He was convinced that the "monitor" existed as part of the language faculty, that speakers could strengthen their monitoring capacity, and that teachers of ESL should develop the methods for doing so. He also maintained, of course, that he himself was the Perfect Monitor.

The other concept he liked to invoke was Harry Whitaker's automatization, the hypothesis that certain complex behaviour patterns, if performed early and often, may become neurologically imprinted as automatic reflexes. Because automatization happens young, adults who mastered Chopin études, triple gainers, or English allophony as children always perform them better than adults who learn them as adults.

I argued that the two concepts seemed incompatible, that no amount of monitoring could compensate for skills so complex that they had to be automatized. Carlos scoffed at my naïveté, declaring that the monitor was precisely the adult mechanism that made up for missed automatization. Automatization is pre-conscious, but developing the monitor, he said, takes conscious effort. It can be done. Monitoring can not only be improved, it can be perfected. He offered himself, of course, as the prime exhibit.

The Perfect Monitor was only a minor episode in the two decades that I knew Carlos. (I met him first at the LSA Institute in 1969, before either of us arrived at the University of Toronto.) But it seems to me it was characteristic of Carlos as an academic-a prototype of what he did best. Although researchers are no closer now than they were then to finding out anything empirical about either monitoring or automatization, which is to say that our reasons for believing that they exist remain intuitive, perhaps even esthetic, Carlos believed in both of them quite passionately. They 'felt' right to him; he considered them part of his 'experience'. He had a 
personal stake in them. Over coffee in the old departmental lounge, he would espouse them not as interesting hypotheses but as facts of life-his life, if not yours. In the classroom, he conveyed those personalized convictions about them to his students. ESL accents and the role of monitoring were not merely casual entries on his course outline. They were real things, personal things he lived with and cared about. And his students got caught up in his enthusiasm, and learned better because of it-learned indelibly, in some cases. I'm sure that, like me, more than a few of those students remember him as, among many other things, the Perfect Monitor.

\section{J.K. Chambers \\ University of Toronto}

I first met Carlos at the ELI at Michigan in the early 70's. Those of us who worked at the ELI in those days were quite a closely knit "family." We knew each other well and respected and loved each other. Carlos was a central part of that family: lively, creative, outspoken; and wherever he was, you would find people around him laughing-seeing the humorous side of things.

I always enjoyed Carlos's dry humour. I don't know how many times I was caught off guard by his tongue-in-cheek comments! One time he sent me a paper he had written on the humour of language learning-a side of learning that we both have always appreciated. He reminded us in the paper of the importance of laughing with-not at-our students as they do outrageous things with language. Carlos practiced what he preached!

The profession will miss Carlos. Here was a person who, from his professional start at Michigan, to his work in Toronto, to his recent leadership in New York, constantly gave of himself. He was an idea person, always planting seeds of ideas in people's minds and then challenging them to carry those ideas out. He was a teacher whose empathy with graduate students inspired them to greater achievements. He served in numerous capacities in TESL Canada and TESOL, always efficiently, kindly, selflessly.

Carlos touched many of us in his stay here in this life. Because of him our profession is stronger, we are more honest with each other, and we can laugh with each other a little more. Thank you, Carlos!

H. Douglas Brown San Francisco State University

Sitting in my first faculty meeting of the ELI in the north university building of the University of Michigan 17 years ago, I had no inkling that the handsome, urbane, impeccably dressed young man, who stood up and 
spoke so articulately about a subject I can now no longer recall, would turn out to be my lifelong friend.

Carlos impressed me then and has continued to leave an imprint on me. I have admired his teaching (he made English Sentence Structure come to life!), his enthusiasm for teaching and learning (which never failed to fuel my own), his insights into theory building and his ability to apply theory to practice, and his skillful administrative and organizational abilities. He has been one of my models of dedication and commitment to our field of second language teaching. But what I appreciate most of all has been his friendship, which he manifested in numerous ways over the years, despite the time and distance that have intervened since those early days in graduate school. I shall miss seeing Carlos, enjoying (sometimes suffering) his distinctive sense of humour, and the boisterous give and take of our conversations, but he will remain forever a significant part of my life.

Rita Wong

San Francisco State University

Carlos Yorio was a great friend and a wonderful professional colleague. Whenever I was working on a new project or had an idea that I wanted to explore, Carlos was always there, offering not only his interest but also his unfailing insight and support. He had a refreshingly pragmatic way of blending theory and practice, and I was continually impressed with how much he knew about so many things. His enthusiasm and energy were infectious, and his commitment to excellence never wavered. His passing is a great loss to all of us. I miss him.

\section{Barry P. Taylor San Francisco State University}

Carlos was my mentor, the one who modelled for me what being a teacher and a professional was all about. Let me give you an example. When I was making a career shift from ESL to the museum field in the late 1970 's, I went through a particularly difficult period. I could not seem to get that all important first job in my newly-chosen profession. Discouraged, I confided in Carlos, "I feel I have no talent." He immediately replied, "Oh, you have a little talent." This, of course, was the exact combination of sympathy and criticism needed to sting me into proving I had more than a little talent. Shortly afterwards, I did just that by getting my first curatorial job. That to me was Carlos, a consummate teacher who knew how to bring out the best in his students, colleagues and friends. I will miss him.

Lynne Kurylo

Royal Ontario Museum 


\section{CARLOS ALFREDO YORIO}

\section{SPECIAL.}

You knew it the first time you met him.

Here was no ordinary person.

You knew it when he walked into a room.

Here was someone very special indeed.

It was intangible . . but you knew it . .

.. his bearing .. . . his demeanor. .

. his sharp observant eye .. . . his crisp clean speech patterns . .

\section{BUT MORE.}

The mind was special.

Cutting through to the core of an issue.

Clear elucidator of complex arguments.

Quick to question the unsubstantiated.

Seeing patterns and relationships.

It was energizing to match wits with him!

\section{BUT MORE.}

The heart was special.

He touched the lives of so many many of us . .

. . in sharing with us . . . . in challenging us . .

. . in supporting us . . . . in warm and caring ways . .

He was a strong and steady advocate for students' needs.

It was a pleasure to call him 'colleague'.

\section{BUT MORE.}

It was a privilege to call him 'friend'.

\section{Joan Morley \\ University of Michigan}

Carlos dressed in sober grey and dark blue, but I always think of him in glorious technicolour. His non-verbal behaviour was colourfully expressive, and his verbal even more so. I was taller than he was, but he always seemed larger than life. Whether it was with a group of friends, or in a huge lecture hall, his charisma would attract the attention which he thoroughly deserved and enjoyed. Even though he never seemed to stand still, he was always close by when you needed him. (In fact, sometimes too close by my anglo-saxon rules of space. He taught me the meaning of proxemics!) 
He also taught me about exotic drinks. We drank Champagne Mimosas in the Rockefeller Centre when I took my daughter to visit New York for the first time. We drank Tequila Sunrises in Mexico City, and Strawberry Daquiris in Miami. It has just occurred to me that he still owes me one!

As my academic mentor, he could stimulate and respond, theoretically challenge and provide practical reassurance, all in the same breath. From the day we met until our last telephone conversation, we had spirited arguments which helped me to view my ideas and the ideas of others more honestly. Our last conversation was hilarious because, as he was critically analyzing some suggestions I had made about learning strategies, the dog next door apparently attacked his garbage, and he could see this from his window. The rest of the interaction was typically Carlos, flavoured with some very graphic epithets, as he tried to decide what was more important to him: telling me why I was wrong or dismembering the dog. The dog won.

Time spent with Carlos was delightful or infuriating but never boring. I shall miss him terribly and know that life will be more drab and grey without him in it.

\section{Marian Tyacke University of Toronto}

I was fortunate to have been among Carlos' earliest students and more so to have worked alongside him in the mid-seventies when he came to the School of Continuing Studies at the University of Toronto.

A kind and inspiring educator, he was concerned that his ESL teachertrainees become model ESL teachers. To this end, he was eager to impart what he had learned not only from books but from his teaching experience. He impressed us with his enthusiasm-sometimes childlike-at hearing about classroom incidents which had some bearing on what he was teaching even when they didn't seem to corroborate his theory. Perhaps this is one of the reasons he endeared himself to all his students. Carlos touched each of us in some way and it will be a long time before we come to grips with his death. His fond memory will always remain with us.

Phyllis Amber Seneca College

For me as 'student' it was first and foremost his teaching 'style'. A good lecturer, yes, but always seeming to be 'straining at the leash' to move away from the lectern and move among his students as if being physically closer to them he could more effectively make his point or reinforce his point. To follow Carlos with your eyes in a classroom meant constantly turning your head to catch him as he paced back and forth about the room. 
More personally, I still remember the spring day in 1974 that Carlos interviewed me for a teaching position in the Intensive programme. Although attentive and charming, he was clearly 'reading me between the lines' and not just the resume in front of him, and I felt quite honoured when a few weeks later I was offered my first class. Imagine my surprise when upon completion of the session, I received a short note from Carlos on which he had copied a very complimentary comment he had received from one of my students. His thoughtful gesture was an enormous confidence builder, and I have kept that small piece of paper all these years.

The same attentiveness and graciousness was demonstrated more recently in the summer of 1987, when during a visit to New York to 'see the sights' with our youngest daughter, Carlos and Gil chose one of their favourite restaurants and all of us spent a wonderful evening together.

He was a special person . . . and I will miss seeing him again.

\section{Vivian McDonough University of Toronto}

Carlos was a friend, colleague and mentor. He encouraged me and many others to make ESL a career, and stood by ready to help us through those early classes and presentations when many of us were learning as we went.

Above all, Carlos was a professional. In the field, he believed in the potential of ESL as an area of study before it was accepted in Canadian universities. He wanted ESL to be recognized as a professional discipline and he set the example through his teaching, numerous conference presentations, guest lectures, publications and activity in professional organizations.

Very recently, Carlos wrote on my behalf for an academic promotion. As I look at the copy he took the trouble to send me I realize it reflects both his willingness to help those he knew and his attention to detail, so typical of his professionalism.

Joan Beyers University of Toronto

I think I can remember Carlos in a hundred places-of course in the classroom, knowing the names of the 40 students after 3 lectures; in the bars of a half-dozen conference hotels; at a party at his place on St. Clair; giving a talk in 1975 to the ESL teachers at George Brown ("I'm just raising the questions-you have to find the answers in your teaching"); Carlos on a flight home after a TESOL Convention ("Just watch-I'll be the only one of us stopped at Customs. The only one."-And he was.); Carlos walking along Queen's Park Crescent that fine, hot summer of 
1983, debating the points of a TESOL Summer Institute lecture just given by Charles Fillmore; Carlos dragging me into his office at the Robarts and sitting me down to look at the latest draft of a paper or plenary he was writing; Carlos at Janet's or Sheila's or Ian's for a dinner party; Carlos making fun of me during a game of Trivial Pursuit ("All the boys and girls who can remember the capital of Afghanistan, raise their hands.")

Through all these events, Carlos laughing or complaining or lecturing or just holding forth, he had a passion and a positiveness that's so rare. I remember Ian preparing a farewell speech when Carlos and Gil were leaving for New York. We talked a lot about what to say-and there was one point Ian was determined to make. That was how Carlos had been the best teacher many of us had ever had. He always assumed you were capable of great accomplishments, convinced you that you were capableand then proceeded to celebrate the accomplishments even more than you did.

Carlos was wild with excitement when Letters from China came out in 1981. I was a student in the TESL Certificate Programme at the time. He arranged for me to give a joint Woodsworth College-Hart House talk and reading, with a wine-and-cheese party afterwards. Of course I was touched and grateful, but I was a bit embarrassed, too, at the attention. "But why?" he asked. "This isn't just good for you, it's good for all of us, for ESL teachers, for the programme, for everyone. It's an accomplishment for all of us. We have to celebrate these things."

\section{Maureen Hynes George Brown College}

March 1988, the TESOL Convention in Chicago. Carlos, in his inimitable way, had organized a dinner outing. We did not, however, arrive at the restaurant in a taxi, but in a limousine also organized by Carlos. He had such style and such class that he always elevated those around him to his level; whether it be in the difference between arriving at a restaurant in a limousine rather than a taxi, or being a professional in the field rather than just an ESL/D teacher. I was sitting next to him at that dinner, and we talked and we talked and we talked, until finally another member of the group further down the table reminded us that there were other people present. Carlos, not only on that particular occasion but on all others, made me feel like an equal, that what I had to say was not only interesting but also important. Carlos always brought out the professional, the inspirational and the personal in all of us. A few months ago a one-page hand-written resume which I had submitted to Carlos in March, 1975 was returned to me, it had formed part of my application for a summer teaching position at the University of Toronto. At the time I knew little, had limited experience and felt presumptuous in making the application. On the one- 
page resume Carlos had written: "Excellent possibility, nice personality and common sense". Fifteen years later those brief comments mean a lot. November 1986, the TESL Ontario Conference in Toronto, Carlos was a plenary speaker. Over a drink in the bar afterwards he was euphoric because an ESL/D teacher, previously unknown to him, had told him of her plans to leave the profession until she heard his plenary. Carlos had inspired her, through what he had said, to continue teaching ESL/D. She thanked him for making her change her mind. That unknown ESL/D teacher and I have a lot in common, we have both been touched by, and inspired by, Carlos.

\section{Janet Dawson Miami, Florida}

Mutual trust and loyalty were fundamental to friendship with Carlos and led to times that now flash through the memory one after anothermoments ranging from shared sorrow to shared laughter. He was a man who could speak volumes without saying a word. An almost imperceptibly raised eyebrow could provide a feeling of complicity that made you feel special, and after all, the ability to make people feel special was one of his greatest gifts.

Sue Brioux University of Toronto

It is a long time since I took a first-year Linguistics course with Professor Yorio (followed by another the next year), and I think it was his first course at the $U$. of $T$. I have always remembered what a fine teacher he was, even in the enormous classes he taught. He conveyed tremendous enthusiasm for his subject, and passed it on to his students; he also projected a sort of warmth toward them, so everyone wanted to work extra hard to please him. In fact, in one course, the class average was so high that the powers-that-be wanted to knock all the marks down to fit a sort of bell curve-but Professor Yorio went to bat for the students and insisted on a paper-by-paper analysis. The result was that everyone managed to hang on to the unusually high marks that resulted from a sound understanding of what he taught, and hard work.

I am sure that anyone who ever took a course of his remembers him as I do-a fine teacher and a warm human being. I am now eighty years old, and it seems to me a great tragedy that he should die in his prime, while he still must have had so much to offer.

Mary Sims 
Perhaps Carlos was such an exciting teacher, and, in my case, doctoral thesis advisor, because he was such an excitable man. New ideas could excite him, good writing could excite him. Unclear thought or bad writing would excite him in a different way. This was not the manipulative, feigned excitement of a calculating pedagogue, but genuine emotion over what people thought and said. How could we not be affected by this deep caring?

\section{Guy Ewing \\ Parkdale Project Read}

I first knew Carlos in his role as the Departmental Graduate Coordinator and Graduate Students' Advisor. And did I need advice those years! I was new to the Department of Linguistics, the courses were new-a whole different ball game! And what was more, I had arrived late in the term from my home country! I needed all the counselling and guidance available, and Carlos did not fail me.

I knew Carlos as my professor. That was when I opted for Applied Linguistics. Everybody, I presume, knows and remembers Carlos for his total commitment to second and foreign language learning and teaching. His courses were not only challenging but memorable in many ways. I loved those moments of dramatization (for Carlos was quite an actor). $\mathrm{He}$ would walk into the lecture room, sit down, bury his head in his folded arms on the table, and then bemoan rather helplessly: "How boring! How boring! Oh. ..."We would all laugh. And when the lecture was over, well, boring? No! not at all. Carlos was just such a good teacher.

I knew Carlos as my supervisor-I was one of his Teaching Assistants for Introductory Linguistics. I had the advantage of benefitting from his sense of organization and from merely watching him teach.

I knew Carlos as a friend, above all. I remember a seminar presentation I made (well, I blew it!). And when I met Carlos later, he said to me out front, "Patrick, you blew that one!" Well, to me, that's a friend. How frank, how simple and how accessible Carlos was to all of us students in the Department of Linguistics. Carlos, we will always miss you.

Patrick Conteh

OISE

Well, Carlos,

We, Hitay and Myriam, first got to know each other when we took your class in ' 82 . Together, we listened to your impeccably prepared and clear lectures, delivered in exquisite English, and we became better learners and better teachers. 
That's why we are remembering you together.

We also remember a talk; your opening lines. The talk was given, if we remember correctly, upon your first visit to Toronto, after you had moved to New York. You began with three answers: "Yes, yes, and no!"

Today, the questions are irrelevant, but not the answers:

Yes, we owe you a lot.

Yes, we will miss you.

and

No, we will not forget you.

\section{Shalom and Merhaba, Myriam Schecter and Hitay Yükseker OISE University of Toronto}

It's as a teacher that we remember Carlos best. We still see him running up and down the aisles of a Sidney Smith lecture hall, wildly gesticulating while explaining dental deletion in Latin phonology. He injected life into generative phonology (no small task!!) in the same way that he injected life into his descriptions of novels, plays and movies. (Movies were always a disappointment after Carlos' descriptions of them.)

It's hard to say exactly what it was that made Carlos such an exceptional teacher. His boundless enthusiasm for the subject matter? His belief that students had opinions worthy of consideration? His ability to make you believe that you, too, could make a difference? Whatever that intangible quality was, those of us who had the privilege of learning from him will never be the same. Carlos made us different and for that we are grateful.

Peter Avery and Susan Ehrlich George Brown College and York University

\section{I remember Carlos.}

I remember Carlos interviewing me for my first ESL job and gently advising me that having a graduate degree in linguistics was not enough and that I had a great deal to learn. And then he interviewed me at another stage in my career and I remember him saying "She knows what she's doing now. Let her do it." I remember xeroxing his letter of recommendation to wallpaper my kitchen.

I remember being very pregnant and playing roulette at Carlos' home. Every time I placed my bet, I knocked over everyone else's chips and Carlos would yell "SIT DOWN, for heaven's sake, SIT DOWN." I remember Carlos waiting up all night for my little girl to be born and appearing with tiny white roses early in the morning, pretending to be "the father" so he could get in to see her-and his comment "She looks just 
like you. She has a big mouth." Uncle Carlos and Uncle Gil would come to her birthday parties with huge furry presents and drink wine and laugh the evening away. And just a few weeks ago, that same child asked me to play "I had the Time of my Life" on the car stereo because it reminded her of Carlos. I remember Carlos making sure that little white roses were there when my son was born; he said it was important.

I remember TESOL conferences after Carlos had left Toronto and having dinner at his home and taking limousines and drinking and gossiping in the hotel bar. And there were heated, yet warm discussions about student needs and how to meet them and methodology and research and our roles in ESL.

I remember plenaries and classroom activities, Stratford festivals and lunches in New York and coffees in Toronto and New Year's Eve and Trivial Pursuits. And I'll always remember walking arm in arm with Carlos along Bloor Street, and he was saying goodbye-really goodbye-and I didn't even know it.

Maureen McNerney York University

Carlos was too much for one paragraph. Teacher/mentor. Friend. Unrepentant city person. Occasional pain in the ass. I loved him dearly.

He used to castigate me for my comments about the sterility of all the glass and stainless steel buildings all over downtown Toronto. I maintained that they were designed and built to be fortresses against the environment, rather than a part of it. He couldn't see that, and would rave instead about the beauty of the same buildings. It finally got to the point where he once introduced me to a friend as "my friend Cam. He likes trees."

It was a joy to disagree with Carlos about almost anything. (And Lord knows he was never at a loss for an opinion.) His arguments were eloquent, articulate, passionate-even when I knew-and he knew that I knew-that he was just as unconvinced of the rightness of his position as I was. Because he had those opinions and was able to defend/explain them, I learned more about the ESL profession (and about the world, for that matter) than I could have any other way. He was never hesitant to share his knowledge or intelligence. That, in fact, was one of his great gifts.

Carlos was also generous with responsibility and the credit that sometimes accompanied it. There was no reluctance to delegate tasks, and no false claims about really wanting to do them himself. But once the job was done there was no second guessing or "you shoudda."

I've seen him reach forward from the back seat of a car to honk the horn when the car in front didn't move out from the stop light quickly 
enough to suit him. He was the kind of guy who'd have no qualms at all about taking the last fried dumpling, even if he knew you wanted it. He could look you straight in the eye and claim that day was night--and make a pretty good case for it, too. He was constitutionally incapable of just listening: If you had a problem, he wasn't interested in hearing about it, he wanted to tell you how to solve it. That could be a touch trying at times.

But he was as honest a person as I've ever known. Intellectually honest, the kind that really counts. If he didn't like something, he'd make it known. Sometimes loudly (I once heard him two offices away from me tell a student, "I am not a liar, sir!"), sometimes so gently that the one being so informed would thank him for the knowledge. By the same token, if he liked something, an idea, say, or a person, he'd make that known, too. Once at lunch with all of us who worked with him he looked around the table and said, "Gee, I like you guys!" Remember his laugh, when something really delighted him?

He couldn't be shocked, and if he was your friend, he wouldn't stop being your friend just because you said or did something stupid. I once said to him, about half way through a particularly rough period in my life, "How come you're putting up with the way I've been acting?" His response was, "Well, you're my friend. Friends put up with that sort of crap from friends."

I've dragged out all the mental photo albums and gone through them, trying to find an image of Carlos that would fit in a single paragraph. Couldn't do it. There are a lot of other memories, of course, that aren't appropriate here; they'd be better served (as would he) by being taken out and exchanged at TESOL conventions with others whose lives he's touched. He's dead. I loved him dearly. I'll miss him greatly.

Cameron Beatty Snow College, Utah 